\title{
Potency of Barnacle in Aquaculture Industry
}

\author{
Daniel A. López ${ }^{1,2}$, Boris A. López ${ }^{1}$, \\ Christopher K. Pham ${ }^{3}$ and Eduardo J. Isidro ${ }^{3}$ \\ ${ }^{1}$ Department of Aquaculture and Aquatic Resources, \\ Universidad de Los Lagos, Osorno \\ ${ }^{2}$ Advanced Research Center, Universidad de \\ Playa Ancha, Valparaíso \\ ${ }^{3}$ Department of Oceanography and Fisheries, \\ Universidade dos Açores, Horta, \\ 1,2Chile \\ 3Portugal
}

\section{Introduction}

\subsection{Biological characteristics}

Barnacles belong to the Cirripedia group (cirri: cirri, pedia: feet) and are, for the most part, sessile crustaceans that live permanently adhered to a substrate that can be inorganic (rock), organic (coral, molluscs, turtles, whales) and even artificial (plastic, wood) (Southward, 1987). They mainly inhabit marine environments; although some species can resist low salinities in estuarine zones (Arenas, 1971), and are distributed bathymetrically from the high intertidal zone to depths of over 1,000 m (Anderson, 1994). They are gregarious, forming dense "patches" of individuals that can completely cover substrates.

The Thoracica superorder is the principal group that assembles the majority of Cirripedia species described. In contrast to other crustaceans, they are characterized by lacking development of the abdomen. This group is divided into three suborders: Lepadomorpha (Fig. 1A), Balanomorpha (Fig. 1B), Verrucomorpha. In general, they present a fragile, chitinous exoskeleton, as a result of which, the majority of species also possess a set of calcareous plates (mural plates and opercular plates) that surround the individual, providing support and defence, as well as, in the case of the opercular valves, associated to feeding, respiration and moulting processes in the specimen. Furthermore, some species have a calcareous base (Southward, 1987).

The thoracic barnacles are filtering organisms with a series of modified articulated appendages, such as a cirral fan, that enables them to capture particles suspended in the water column, feeding, principally, on microscopic algae and the larvae of other invertebrates (Anderson, 1994). These species are simultaneous hermaphrodites, undertaking crossed fecundation or copulation between adjacent individuals by means of elongation of a penis. The ovary is located in the basal part of the organism. After fecundation, the egg mass becomes compact, forming the so called "ovigerous lamellae", 
within which embryonic and early larval development of specimens occurs. Barnacles incubate eggs within the body cavity up to the larval nauplius I stage, which is released into the water column, initiating a planktonic, free-swimming life that can last two to four weeks. This larval stage, and principally their transport, is influenced by local oceanographic factors, as well as meso and macro-scale processes, such as currents, winds and upwelling (Roughgarden et al., 1988; Gaines and Bertness, 1992; 1993; Pineda, 2000). Larvae grow in size during this stage, increasing the number of appendages and advancing through successive stages (nauplius larvae II to nauplius VI), until converting into the competent larvae denominated cyprid. The cyprid presents a bivalve form, is lecitotrophic and possesses a sensorial system that enables it to search for an adequate substrate, where texture, colour, quantity of light and biofilm are variables that determine attachment. Immediately after cyprid larval settlement, they undergo metamorphosis, adopting the form of an adult specimen, where factors such as depredation, competition and physical disturbances (Gaines \& Roughgarden, 1985; Minchinton and Scheibling, 1991, Thomason et al., 1998) play an important role in the early survival of individuals. Under laboratory conditions, it has been described how aspects, such as type and concentration of food, temperature and larval density are key factors influencing duration and survival during larval development (Qiu and Qian, 1999; Mishra et al., 2001; Thiyagarajan et al., 2003a; $2003 \mathrm{~b}$ ). In addition, with respect to induction of larval settlement, it has been observed that a great variety of chemical signals trigger this response, associated, principally, with three types of source: presence of conspecific indivuduals, presence of prey species and microbial films (Rodríguez et al., 1992).

The lepadomorph barnacles ("goose-neck" or "stalked barnacles") are characterized by their fleshy stalk used to adhere to the substrate, as well as calcareous plates, found only in the apical zone of the animal, denominated capitulum. These species mainly inhabit the intertidal zone and are considered neustonic species, adhering to floating structures (Fig.1A). On the contrary, the balanomorph barnacles ("acorn barnacles" or "non-stalked barnacles") do not possess a stalk or peduncle, and adhere directly to the substrate by means of a base that can be membraneous or calcareous. They possess greater development of the calcareous plates, with between 4 and 8 overlapping plates that form a supporting

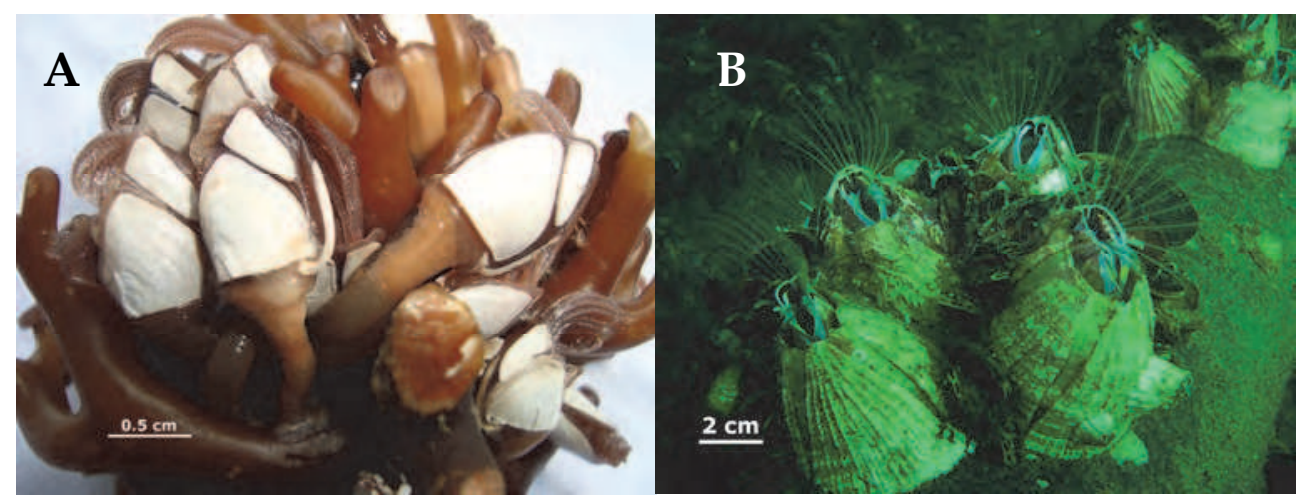

Fig. 1. General view of the barnacles. A. Lepadomorpha. B. Balanomorpha. 
structure. Furthermore, two pairs of plates are located in the upper zone, forming the opercule (terga and scuta) (Fig. 1B). These species are habitual members of the shallow intertidal and subtidal communities of the coastal area. Finally, the verrucomorph barnacles ("wart barnacles") are small organisms, without a peduncle, characterized by their asymmetric opercular plates, and are more frequent in deep-waters, where they appear as epizoos of other invertebrates (Anderson, 1994).

\subsection{Commercially important barnacle species worldwide}

In spite of the wide variety of barnacle species on a global scale, only a few are commercially important, due to the small size of the majority of these organisms (Table 1). Of the lepadomorph barnacles, Pollicipes pollicipes (Leach, 1817), the "goose neck barnacle", is the best known culinary resource. It is extracted along the coasts of Galicia (Spain) by fishermen's organizations, known as unions ("perceberos"), and can reach a height of 10 to $12 \mathrm{~cm}$. Approximately 300-500 ton/year are captured, and demand is high (Molares \&

\begin{tabular}{|c|c|c|c|c|}
\hline & Scientific name & Common name & $\begin{array}{l}\text { Geographic } \\
\text { distribution }\end{array}$ & Production type \\
\hline \multirow{4}{*}{ 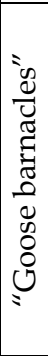 } & Pollicipes pollicipes & $\begin{array}{l}\text { "Spanish goose } \\
\text { barnacle" }\end{array}$ & $\begin{array}{l}\text { Spain, Portugal, France, } \\
\text { Morroco }\end{array}$ & $\begin{array}{l}\text { Fisheries by } \\
\text { fishermen's unions } \\
\text { ("perceberos") }\end{array}$ \\
\hline & Pollicipes polymerus & $\begin{array}{l}\text { "Canadian goose } \\
\text { barnacle" } \\
\text { "Leaf barnacle" } \\
\end{array}$ & Canada, USA & Local fisheries \\
\hline & Pollicipes elegans & "Pacific goose barnacle" & Mexico, Ecuador, Peru & Local fisheries \\
\hline & Capitulum mitella & $\begin{array}{l}\text { "kamenote" or } \\
\text { "Japanese goose } \\
\text { barnacle" }\end{array}$ & South of Japan & Artisanal fisheries \\
\hline \multirow{8}{*}{ 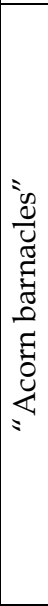 } & $\begin{array}{l}\text { Austromegabalanus } \\
\text { psittacus }\end{array}$ & $\begin{array}{l}\text { "picoroco" "giant } \\
\text { barnacle" }\end{array}$ & Perú, Chile, Argentina & $\begin{array}{l}\text { Artisanal fisheries/ } \\
\text { semi industrial } \\
\text { aquaculture }\end{array}$ \\
\hline & Balanus nubilus & "giant acorn barnacle" & Alaska, Canada, USA. & Local fisheries \\
\hline & Balanus rostratus & "mine fujit subo" & Russia, Northern Japan & Local fisheries. \\
\hline & Megabalanus rosa & $\begin{array}{l}\text { "aka fujit subo" } \\
\text { "rose barnacle" } \\
\end{array}$ & Japan & Local fisheries. \\
\hline & Tetraclita japonica & \begin{tabular}{|l} 
"kuro fujit subo" \\
"black barnacle"
\end{tabular} & Japan & Local fisheries. \\
\hline & Tetraclita kuroshioensis & "hat fujit-subo" & Japan, Indonesia & Coastal fishermen \\
\hline & Megabalanus azoricus & "craca" & Azores Islands (Portugal) & $\begin{array}{l}\text { Local fisheries/ } \\
\text { experimental } \\
\text { aquaculture }\end{array}$ \\
\hline & \begin{tabular}{|l|} 
Megabalanus \\
tintinnabulum
\end{tabular} & "claca" & $\begin{array}{l}\text { Entire tropical zone of the } \\
\text { Atlantic and Indian } \\
\text { Oceans. Canary Islands } \\
\text { (Spain) }\end{array}$ & Local fisheries \\
\hline
\end{tabular}

Table 1. Commercially important barnacle species and species used for human consumption worldwide. Scientific and common names, geographic distribution and production types. Source: Modified from López et al., (2010). 
Freire, 2003). Overexploitation of natural banks of this resource has prompted regulation of extraction activity. Other species of the same genus, such as P. polymerus (Sowerby, 1833) and $P$. elegans (Lesson, 1830), are commercially significant on a local scale in Canada and Perú, respectively, and, secondarily, are used to supply the Iberian market (Bald et al., 2006; Jacinto et al., 2010). On the other hand, the species Capitulum mitella (Linnaeus, 1758) or "stalked barnacle", distributed along the southern coast of Japan, is smaller ( $<5 \mathrm{~cm}$ height) and is only consumed on the local market.

Of the balanomorph barnacles (Table 1), the most commercially important species is Austromegabalanus psittacus (Molina, 1782) "picoroco" or "giant barnacle" a large species that can reach a height of $30 \mathrm{~cm}$. Distribution ranges from southern Perú to the austral zone of southern Chile and the southern coast of Argentina (Pilsbry, 1916; Young, 2000, López et al., 2007a). It is exploited on a small scale by artisanal fisheries and catches are concentrated in southern Chile (420S), with landings that fluctuate between 200-600 ton/year (Fig. 2). Average commercial size is $2.2 \mathrm{~cm}$ carino rostral length. Another giant species is Balanus nubilus (Darwin, 1854), distributed along the Pacific coast, from Alaska to North America, and consumed by indigenous coastal communities (Morris et al., 1980). Megabalanus azoricus (Pilsbry, 1916) "craca", is a subtidal species, limited to the Azores Islands archipelago (Portugal), in the Atlantic Ocean (Southward, 1998; Regala, 1999; Santos et al., 2005). It is exploited locally, and specimens over $1 \mathrm{~cm}$ carino rostral length are consumed fresh (Lotaçor, 2006; Pham et al., 2008). The analysis of the enterprises LOTAÇOR S.A data, from 1980 to 2010 shows that reported landings are modest, ranging from 1 to 3.3 ton/year on the 80's, stabilized bellow 1ton/year in the 90's, have raised considerably between 1999 to 2003, when a historic maximum of 7ton/year was auctioned. Since 2003 the landings have been dropping to about 3.7ton/year in 2010. From 2005 to 2010, the average first selling price has been around $3.90 € / \mathrm{kg}$, with a minimum of $0.20 € / \mathrm{kg}$ and a maximum of $20 € / \mathrm{kg}$. The real catches and economic value of the resource may be substantially higher than the reported. The species is highly appreciated locally, and traditionally caught along the shores, by the people and for their own consumption. Dionisio et al., (2009), based on LOTAÇOR data, described some socio-economic aspects of this fishery and estimate a per-capita consumption between 88 and 241g/year. The Megabalanus tintinnabulum (Linnaeus, 1758) "claca" species is extracted in the Madeira archipelago (Portugal), and the Canaries (Spain). It is a cosmopolitan species whose distribution covers the entire tropical zone of the Pacific, Atlantic and Indian oceans (Young, 1998).

In the Japanese market, balanomorph barnacles are referred to as "fujit-subo". In northern Japan, mainly in the Aomori prefecture, the Balanus rostratus (Hoek, 1833) "mine fujit-subo" is commercialized, and can reach a height of $5 \mathrm{~cm}$, with landings of around $10 \mathrm{ton} /$ year. Other smaller species of balanomorph barnacles, Megabalanus rosa (Pilsbry, 1916) "aka fujitsubo" and Tetraclita japonica (Pilsbry, 1916); "kuro fujit-subo", are also extracted locally in the central-southern zone of Japan. Similarly, in Indonesia the Tetraclita kuroshioensis Chan, Tsang \& Chu, 2007, "hat fujit-subo", is consumed by coastal communities.

\section{State of barnacle culture on a world scale}

In spite of the commercial importance of various species of barnacles, development of activities associated with cultures is limited to a few species (López et al., 2010). Among the lepadomorphs, previous information on Pollicipes pollicipes is available related to obtaining 


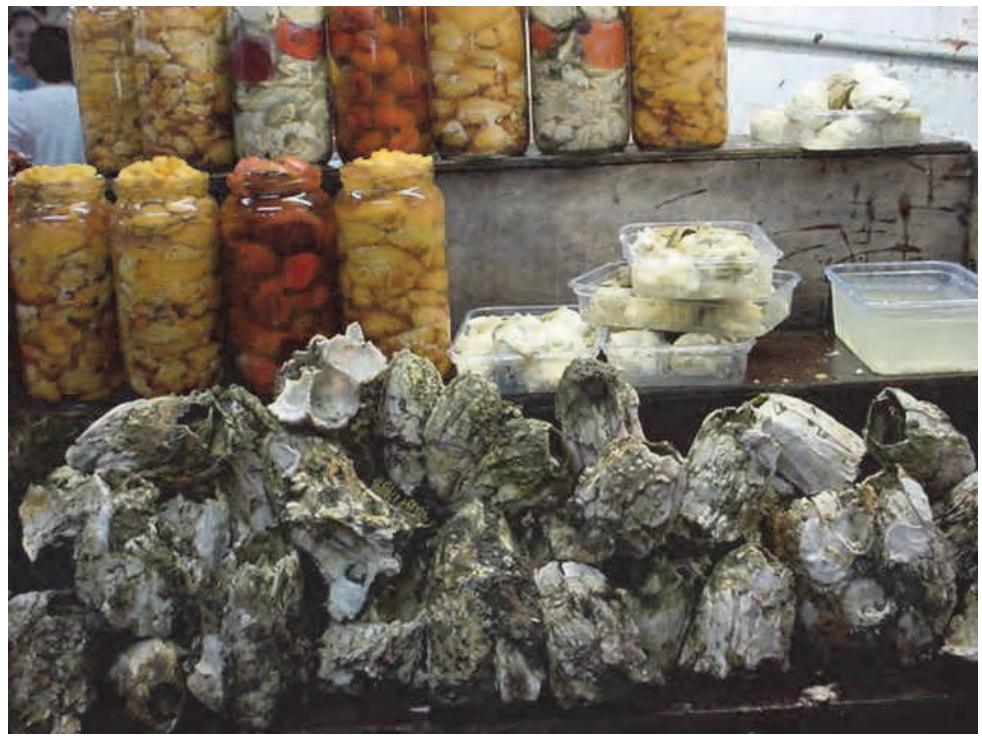

Fig. 2. "Giant barnacle" in a local market in Puerto Montt city, southern Chile.

juveniles in artificial floating substrates (Goldberg, 1984). Results have been scarce, mainly because, in this species, larval settlement is determined by the presence of conspecific adults (Molares et al., 1994; Cruz et al., 2010). Among balanomorph barnacles, similar experiments have been undertaken on Megabalanus azoricus in the Azores islands, where technologies have been designed for installing collectors in the water column. The results indicate that larval settlement occurs, although it is still not possible to ensure that levels are sufficient for industrial scale cultures (Pham et al., 2008; Pham \& Silva, 2010; López et al., 2010). Thus, progress has been made, on an experimental level, with these two species, in the area of spat collection from the wild. The only species where studies have advanced from experimental to semi-industrial cultures, is the "giant barnacle"," picoroco", Austromegabalanus psittacus, on the Chilean coast. In this species, it has been shown that levels of spat collection from the wild will permit the development of commercial cultures. Similarly, the growth rates enable specimens of a commercial size to be obtained over a short period of time (López, 2008; López et al., 2010). Furthermore, low cost production technologies have been developed to obtain spat and to enhance growth. The yield and economic feasibility of various products have also been evaluated (Bedecarratz et al., 2011).

In Megabalanus azoricus, culture activities are incipient. This species is an intertidal barnacle found strictly in areas characterized by strong water flows around the Azorean coastline. It is a highly appreciated shellfish, whose natural populations are subject to intense exploitation (Santos et al., 1995). As a result, the regional authorities have identified the need to conduct trials with a view to developing aquaculture technologies for this species (Pham et al., 2008). Initial results for this species are encouraging (Pham et al., 2011), but much more research is required.

One aspect critical to barnacle species culture is present levels of knowledge with regard to: the particular biological characteristics of life cycle; the dispersion and behaviour of 
competent larvae, as well as ecological and functional aspects of juveniles during growth. From experiences undertaken to date, the main difficulties affecting culture are the following: (a) juveniles cannot be obtained from the wild, or can only be obtained in very limited quantities. It may also be possible to procure juveniles through larval cultures in hatcheries; however this increases costs considerably. The limited amount of spat obtained from the wild can be associated with various aspects, such as: - low supply of competent cyprid larvae; - substrates that are inadequate for the exploratory and attaching behaviour of the competent cyprid larvae; - lack of synchronization between period of maximum competent larvae quantities and the installation of artificial substrates (spat collectors) in the water column; - high spatial and temporal variation in spat collection, associated with climatic, oceanographic and topographic factors (Goldberg, 1984; Lagos et al., 2008; Andrade et al., 2011). (b) high levels of unpredictability in competent larvae supplies, that operate on a macro and meso-scale in the ocean. Consideration must be given to the fact that barnacles can form metapopulations and larval dispersion can be very wide (Lagos et al., 2005); (c) problems during growth related to the presence of predators or species that compete for the substrate or food (Pham \& Silva, 2010); (d) density-dependent effects associated with mass recruitment (Hills \& Thomason, 2003); (e) heavy weight of the shell, that occurs mainly in balanomorphs species. This also generates low harvest yields.

On the other hand, the main advantages associated with the biological characteristics of the barnacle species are: (a) possibility of obtaining spat from the wild; (b) gregarious larval settlement, which, if suitable substrates are available, can ensure an adequate supply of spat; (c) internal embryonic development in the case of balanomorphs barnacles, that limits early mortality and d) filter feeding, that permits suspended cultures without provision of exogenous feed.

Future projections for barnacle culture are aided by the wide-ranging and diversified literature available on larval development in various species; specifically, on aspects such as: duration, effects of environmental factors and feeding, as well as ecological, physiological and behavioural factors associated with larval settlement and recruitment (Walker, 1995; Jenkins et al., 2000; Dionisio et al., 2007; Tremblay et al., 2007; Pineda et al., 2009). Although this information is mainly related to species that are not commercially important, it can be used to optimize barnacle culture.

\section{Spat collection}

\subsection{Barnacle life cycle}

Knowledge about the barnacle life cycle is essential in order to design culture strategies. Identification of the embryonic and larval development particularities - when, where and in what magnitude they occur - will permit the elaboration of production technologies that are suitably adapted to these characteristics.

The life cycle of barnacles that are cultured, or in the process of being cultured, such as the "giant barnacle" and the "craca", presents characteristics that facilitate semi-intensive cultures. The fact that fecundation is internal and that the embryonic stages are incubated, determines that mortality during the early stages of development is lower than in many invertebrate species, such as mussels and clams, where fecundation is external and the 
entire ontogenetic development occurs in the water column. Nevertheless, during planktotrophic larval development, mortality occurs according to the duration of this phase. Similarly, larvae experience wide dispersion that determines high variability in the quantity of competent larvae, both spatially and temporally. This aspect is important when determining the location of the culture centre, in terms of provision of spat from the wild. On the other hand, the high selectivity of the competent larvae, conditions the choice of artificial substrates, that must satisfy the biological and physical-chemical requirements necessary for larval settlement. The cyprid larva possesses a complex sensorial apparatus associated with the need to evaluate the substrate where larval settlement will occur. This stage is crucial to larval effectiveness and determines the subsequent viability of specimens.

\subsection{Barnacle spat collection from the wild. Culture technologies: The cases of Austromegabalanus psittacus (Chile) and Megabalanus azoricus (Portugal)}

Technologies for obtaining spat from the wild have only been developed for two species of balanomorphs. In the case of the "giant barnacle", Austromegabalanus psittacus, it is possible to obtain quantities of spat that can sustain the development of commercial cultures.

The "giant barnacle" is bathymetrically distributed in the shallow subtidal zone (5-7 m depth), although, occasionally, it can also be found in the lower intertidal zone. Furthermore, it is an encrusting species, with a considerable presence associated with the fouling of ships, culture systems and pier support structures (Brattström, 1990; López et al., 2007a). In cultures, it has been possible to take advantage of its high spatial variability and the wide range of substrate-types on which larval settlement develops. Different types of collectors have been used as spat catchment from the wild, including artificial substrates that differ in texture, size, form, colour and buoyancy. In this species, materials tested included $900 \mathrm{~cm}^{2}$ rectangular plates of expanded polystyrene, polythene and synthetic felts ("bidin"), treated with tar. In addition, polythene tubular substrates measuring 70 to $100 \mathrm{~cm}$ (equivalent to 2,200 to 3,000 $\mathrm{cm}^{2}$ useable attachment surface) were tested (Fig. 3). Each collector system is composed of three substrate units, joined by polypropylene cables that are placed vertically in the water column from surface levels down to $8 \mathrm{~m}$ depth, suspended from floating systems (long-lines or culture rafts) in shallow, wave protected or semiprotected bays .

According to results, artificial spat collectors with the following characteristics ensure high spat collection levels: they should be innocuous (do not affect settled organisms), with rough textures, dark colour and low buoyancy. Spat preference for these characteristics is explained due to the sensorial characteristics of the competent larvae at the moment of attachment to the substrate. These possess negative phototaxism (preference for low luminosity), positive geotaxism (preference towards the bottom) and rugofilic behaviour (preference for rough substrates).

Spat density levels have varied according to type of collectors, obtaining values ranging from 0.01 individuals $/ \mathrm{cm}^{2}$ up to 0.2 individuals $/ \mathrm{cm}^{2}$, with substrate coverage of close to $100 \%$.

In the Azores, spat collection and growth experiments in Megabalanus azoricus were initially conducted on PVC tubes with recruitment densities reaching up to 800 barnacles/ $\mathrm{m}^{2 *}$ month 


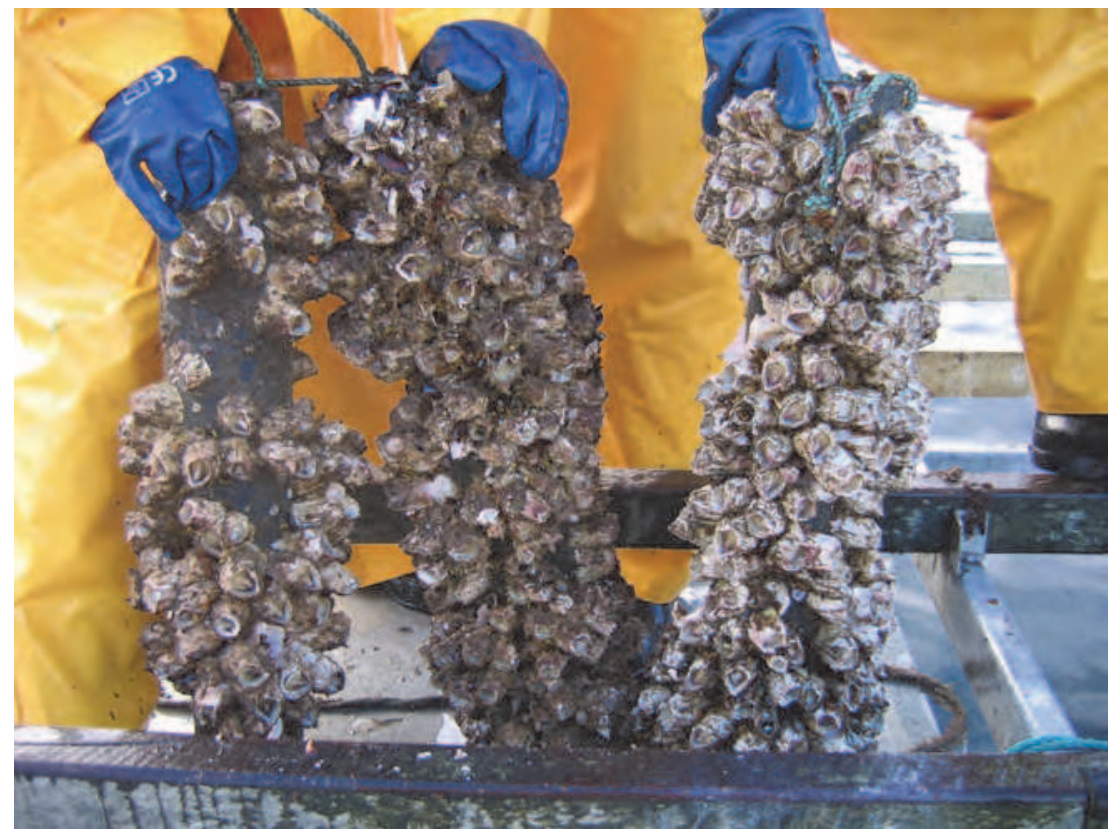

Fig. 3. "Giant barnacle", Austromegabalanus psittaccus, spat collection from the wild, southern, Chile.

during late spring/early summer (Pham et al., 2011). Recent experiments showed that the choice of materials and their orientation are important factors to be considered for optimizing recruitment values and future spat collector designs (Pham et al., unpublished data). Densities on material placed horizontally, whatever its category, are higher than when material is placed vertically. This difference is particularly pronounced for the most efficient material tested, PVC plates. PVC plates should be considered for the design of spat collection structures.

The private sector has tested a pilot structure for the production of barnacles (Pham \& Silva, 2010). The structure tested was designed for both phases of the culture cycle: (a) spat collection and (b) ongrowing. The system was capable of holding 12 PVC tubes within a single structuring frame and was placed at $8 \mathrm{~m}$ depths over a period of 1.5 years. Results were satisfactory, as more than 9,000 barnacles of commercial size were produced with low mortality rates. Work is being currently being conducted to improve the design and efficiency of the system, based on recent results.

\subsection{Spatial and temporal variability}

Spat collection from the wild can vary in spatial on different scales (between latitudes, between locations, between depths, between types of substrate) and temporal terms (interannual, seasonal, monthly), given that natural populations of barnacles function as metapopulations, that is, there is a continuous exchange of larvae between geographically adjacent populations by means of passive transport by currents. Thus, abundance of 
individuals at a given site does not depend solely on the stock of breeders from that location, but also on that of more distant zones. Local oceanographic factors exert an influence, as do variables operating on a meso and macro-scale. In the case of the "giant barnacle", spat collection has been evaluated using artificial collectors in different sites along the Chilean coast, and at different depths and periods of the year. There is a temporal pattern in larval settlement, given that spat capture in artificial collectors is greater in the spring-summer period, principally between October and January, observing a second settlement period in the autumn, during the months of March and April. This is associated with the fact that gonadal maturity reaches its highest values when water temperature and food supply increases. Latitudinal differences have been evaluated in three sites along the

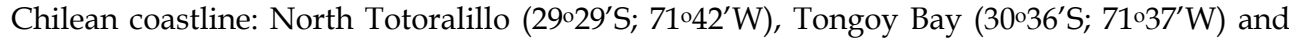
Metri Bay (41036'S; 72042'W); the former two are located in the northern zone of Chile and the third, in the south of the country. All three sites are characterized as being shallow, wave-protected or semi-protected bays. There are marked climatological and oceanographic differences along the length of the Chilean coast, principally in temperature, which is higher in the northern zone. After 9 months, density of specimens recruited (number of specimens $/ \mathrm{cm}^{2}$ ) in the collectors differed between sites, with significantly higher densities in the locations of North Totoralillo than in Tongoy Bay and Metri Bay. Thus variability in spat collection does not have a latitudinal pattern, but rather varies from location to location. In addition, differences have been reported between types of collectors, spat collection being greater in the tubular plastic collectors than in the plates, which could be associated with the different surface/volume relationship.

Bathymetric variability also exists between collectors located on the surface and those located at greater depths. Cultures are more effective at greater depths, although no variations where recorded as at depths of over $4 \mathrm{~m}$; this could be associated with the positive geotactic and negative phototrophic behaviour of the competent larva.

In some locations pronounced inter-annual variations in spat collection of spat from the wild have been verified. Oceanographic aperiodic events, such as ENSO (El Niño Southern Oscillation) and salinity variation on a local scale, could account for these results.

Spatial-temporal variability in spat collection from the wild limits the development of industrial cultures. As a result, it may be advisable to develop mass cultures of the "giant barnacle" in locations that are particularly apt for spat collection, and to establish other sites for the growth process. This practice has been used for many years in mussel cultures (Mytilus chilensis) in southern Chile.

Recent records indicate that the probability of local "giant barnacle" presence is associated with variables that are related to productivity (e.g. nitrate concentration, phosphate). This may be related with processes of coastal upwelling,that modify the physical-chemical regime of the coastal ocean. Furthermore, chlorophyll concentration and its variability are important variables that account for the presence of juveniles and adults, probably related to the trophic relationships of these filtering organisms.

In $M$. azoricus, results collectec monthly from settlement panels located in two sites off Faial Island, over a period of 2.5 years, revealed that recruitment takes place all-year round, with a peak in the summer, from early June until the end of September, coinciding with an increase in water temperature. This same study showed that newly settled barnacles (less 
than 15 day old) have a base diameter ranging between 0.79 and $2.80 \mathrm{~mm}$ and after two months can reach up to $12 \mathrm{~mm}$. This large size and rapid initial growth increases the competitive capacity of $M$. azoricus recruits in relation to other barnacle species settling on the plates (Chtamalus montagui and Balanus trigonus).

\subsection{Optimization models for spat collection from the wild}

Dynamic models have been applied to "giant barnacle" spat collection from artificial substrates in the wild (Andrade et al., 2011). These models enable us to establish the variables involved in the spat collection process, the relationships between them and their relative effect on spat harvest. The dynamic hypothesis proposes that the number of "giant barnacle" spat obtained from the wild is influenced by competent larval abundance (cyprid density) over time, substrate availability and mortality after larval settlement. The number of factors affecting their spatial-temporal variability, illustrates the complexity of the spat collection process and the difficulties that exist with respect to predicting results. Simulation tests to establish consistency of the model were undertaken, using empirical background information obtained from semi-industrial cultures in southern Chile. In these cultures, average spat density in artificial collectors fluctuated between 0.1 and $3 \mathrm{spat} / \mathrm{cm}^{2}$, while early mortality was below $90 \%$. If artificial collectors of $10,000 \mathrm{~cm}^{2}$, suspended from $100 \mathrm{~m}$ long lines are used, between 8,000 and 9,000 "giant barnacle" spat will be required to produce a harvest of 1 gross ton. Synchronization between cyprid abundance levels and installation of artificial substrates in the water is critical to achieve maximum collector efficiency. A period of less than 1 week out of synchronization, produces significant losses $(60-70 \%)$ in spat production. When deployment of collectors and maximum quantity of competent larvae are synchronized, an increase of almost double the number of spat can be obtained. Quantity of competent larvae, as well as substrate quantity and quality, are key factors to achieving adequate spat provision from the wild, enabling the development of commercial cultures.

\subsection{Spat's production in hatcheries}

To date, barnacle larval cultures have not been undertaken on a commercial scale; however considerable experience has been gained with regard to the larval development of different species, studying, not only the effect of environmental and feeding factors on survival and duration of the entire development process, but also the variables that influence larval settlement. Larval development, and the factors that influence it, has been studied in various species of lepadomorphs and balanomorphs (Miller et al., 1989; Molares et al., 1994; Yan \& Chan, 2001; Dionisio et al., 2007; Li et al., 2011).

Spat production in hatcheries possesses various advantages over obtaining spat by collection from the wild. Production can be programmed over time, and is not dependent on the spatial-temporal variability of the larval pool in the environment. The energetic quality of the cyprid larvae can also be improved, that will be reflected in the percentage of larval settlement, size and growth rate of juveniles (Thiyagarajan et al., 2002; Thiyagarajan et al., 2003b; Desai \& Anil, 2004). Post-settlement mortality can be, for the most part, reduced or completely eliminated.

Experiences related to the production of balanomorph barnacle larvae in the laboratory, date back considerably (Knight-Jones, 1953; Rittschof et al., 1984; Brown and Roughgarden, 
1985). Cyprid have been obtained in various species and larval settlement trials undertaken (Yan, 2003; Desai and Anil, 2004; Anil et al., 2010; Li et al., 2011).

In species such as Balanus amphitrite, trials have been carried out with different diets and temperatures, establishing development periods that can fluctuate between 4 and 18 days (Qiu and Quian, 1999), which indicates the influence of these factors on culture success. Microalgae densities of the genera Chaetoceros sp, Skeletonema and Isochrysis, vary from $1 \times 10^{5}$ to $10 \times 10^{5}$ cells $/ \mathrm{ml}$. In this species, survival has exceeded 90\% (Qiu and Quian, 1999; Mishra et al., 2001). Percentage of larval settlement can vary from $10 \%$ to $80 \%$, depending on the culture conditions, the substrate type and the use of inductors (Rittschoff et al., 1984; Mishra and Kitamura, 2000; Mishra et al., 2001; Thiyagarajan et al., 2003b).

With regard to larval settlement induction, a great variety of chemical signals have been described as fundamental to trigger the larval settlement response. Natural inductors have been characterized, based on studies of larval settlement response as a consequence of natural substrates and have been associated, mainly, with three types of sources: conspecific individuals, prey species and microbial films (Rodríguez et al., 1992). Different kinds of microbial biofilms have been described as important inductors of larval settlement in benthonic marine invertebrates. Induction has been observed both by diatom and cyanobacteria biofilms (Akashige et al., 1982), as well as by bacterial biofilms (Kirchman et al., 1982; González et al., 1987). Induction by bacteria has been widely studied; the positive effect of these types of biofilm has been observed in barnacles (Maki et al., 1988, Maki et al., 1990). The settlement response associated with these biofilms would be generated, apparently, by the presence of polysaccharides or extracellular glycoproteins attached to the bacterial wall (Kirchman et al., 1982, Hadfield, 1986), or, alternatively, soluble compounds released by the biofilms (Bonar et al., 1990). An increase in the settlement inductive potential of older bacterial biofilms was a recurring factor observed (Maki et al., 1989, Pearce and Scheibling, 1990, Mataxas and Saunders, 2009). Similarly, the contrary effect has been described (Maki et al., 1989).

In synthesis, sufficient knowledge is available on which to base the design of barnacle hatcheries, although the transition still has to be made from the experimental to commercial level. No information is available with regard to the costs that this would imply. As commercial cultures are implemented, the development of spat production in hatcheries will become a necessity, in order to improve predictability and quality in spat production.

\section{Growth}

\subsection{Production technologies}

Technological designs must ensure specimens have the best access to food and water flow during the growth phase in suspended barnacle cultures. Similarly, space availability must be sufficient to maintain animals up to the harvest stage. As is the case in spat collection systems from the wild, materials used must be innocuous. Weight must also be compatible with suspension from rafts or long-lines, ensuring easy manipulation and costs that are compatible with a commercial activity.

There are two types of production technologies for the growth phase of the "giant barnacle": "Cultch" systems - corresponding to technologies that maintain the specimens 
over the period from spat collection, during growth, through to the harvest stage. Substrates used have included plates and $900 \mathrm{~cm}^{2}$ to $2,200 \mathrm{~cm}^{2}$ polythene tubes, suspended vertically in groups of three units. One advantage is that harvesting of spat is not necessary and this system can be more effective, because specimens are less exposed to mechanical manipulation, and, therefore, suffer fewer mortalities. In the "cultchless" system, two different production technologies are used, one for obtaining spat from the wild and another for growth. Spat harvest occurs approximately four months post-larval settlement. Subsequently, individuals are transferred to a growth system where they remain until the harvest stage. The surfaces used as artificial collectors must permit the innocuous extraction of juveniles. Since specimens are cemented to the collector substrate, a surface must be used that avoids damaging the calcareous structures, particularly of the basal zone, when the specimens are detached. Expanded polystyrene and felts ("bidin") covered with tar have been used as substrates, with an area of $900 \mathrm{~cm}^{2}$ to $1,600 \mathrm{~cm}^{2}$. For subsequent growth, trays can be used or specimens can be attached with adhesive to a new surface. The best results have been obtained with the "cultch" systems. Both the "cultch" and "cultchless" systems are located on floating structures (long-lines or rafts) suspended from surface levels to a depth of $8 \mathrm{~m}$, in shallow wave-protected or semiprotected bays. Maintenance and cleaning of the systems is necessary during the growth phase eliminating, periodically, the accumulation of sediment and fouling (mainly mytilids, ascidians and other species of barnacles), in order to avoid mortalities by suffocation and overgrowth by other species.

\subsection{Spatial and temporal variability: Results in the "giant barnacle"}

In balanomorph barnacles, a density-independent estimator of growth is the carino-rostral length or opercular length, corresponding to the maximum rectilinear distance between the carinal plate and the rostral plate (López et al., 2007b). Other growth estimators, such as mural plate height or basal diameter, are inadequate growth indicators, because they are modified by growth density.

Average commercial size of the "giant barnacle" in Chile is $3.5 \mathrm{~cm} \pm 0.6$ carino-rostral length (approximately $10 \mathrm{~cm}$ height). Specimens of around $2 \mathrm{~cm}$ carino-rostral length can be found in local markets,. Nevertheless, specimens from natural banks can reach sizes in excess of 6 $\mathrm{cm}$ carino-rostral length and more than $30 \mathrm{~cm}$ height. Shell height depends on the degree of aggregation during growth, due to the development of a modified base generated in the hummocks (López et al., 2007b).

Growth rate varies according to depth. Twenty months after larval settlement, average carino-rostral length of "giant barnacle" specimens growing at depths of between 4 and $6 \mathrm{~m}$, was $3.4 \pm 0.17 \mathrm{~cm}$, while the average size of individuals growing at depths of between 1 and $2 \mathrm{~m}$, was $2.92 \pm 0.14 \mathrm{~cm}$ (López et al., 2008a).

If minimum commercial size on the Chilean market is considered $(2.1 \mathrm{~cm}$ carino-rostral length), the culture period, from larval settlement up to harvest, can be 7-8 months. Nevertheless, recent studies in the northern zone of Chile show a relative increase in growth in comparison to the results obtained in the southern zone, probably associated with the differences in water temperature. In the north, specimens of a commercial size $(>2 \mathrm{~cm}$ carino-rostral length) have been obtained over a period of only 4-6 months (Fig. 4). 


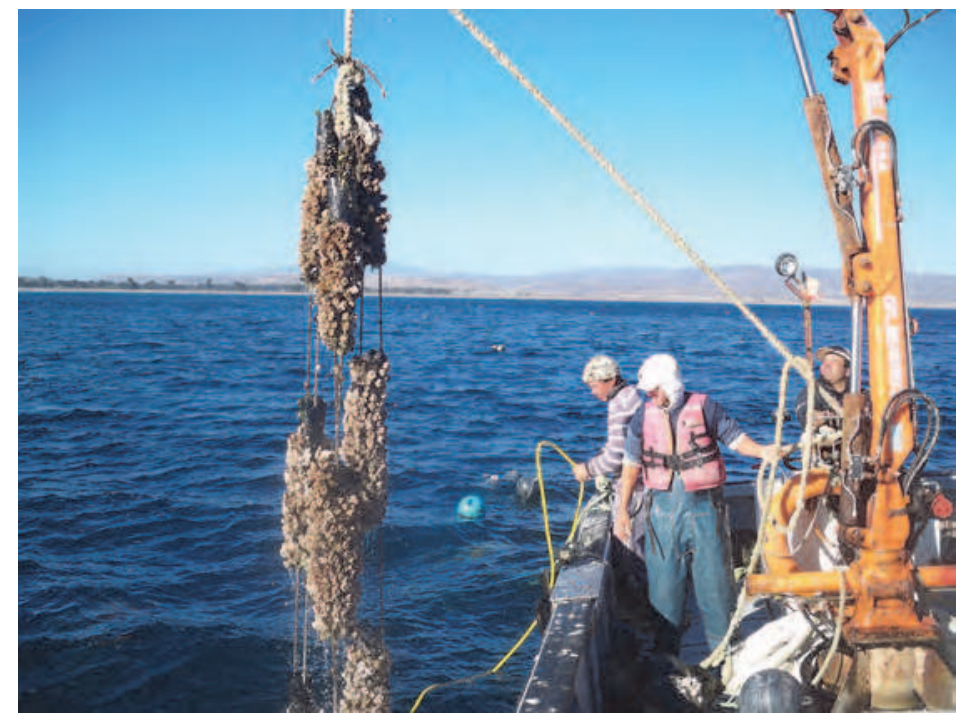

Fig. 4. "Giant barnacle" culture growth system in northern Chile.

Instantaneous growth rates decrease with age, fluctuating from $0.03 \mathrm{~cm} /$ day carino-rostral length at the beginning of growth, to $0.0005 \mathrm{~cm} /$ day carino-rostral length after 20 months.

For the Chilean market, "giant barnacle" harvest should occur between 18 - 24 months, depending on the season the collectors are placed in the water. Prior to harvesting, the majority of specimens must have reached over $3 \mathrm{~cm}$ carino-rostral length. Nevertheless, the culture period can vary according to the requirements of each market. If, eventually, the "giant barnacle" were to be used as a simil of the "fujit subo" on the Japanese market, the culture period would be substantially less.

Productivity in "giant barnacle" culture systems is extremely high, taking production by extractive fisheries as a point of reference. National average gross production of this resource by small-scale local fisheries is around 200 ton/year; this could be obtained with only 20 to 30 long lines. A double, $100 \mathrm{~m}$ floating long-line can produce between 7 and 10 gross ton of total biomass in one season. This can signify approximately 2 ton wet weight of soft parts. Each tubular system of approximately $1 \mathrm{~m}$ in length, can produce, on average, 15 $\pm 8 \mathrm{~kg}$ of biomass, equivalent to an average of 100 specimens of commercial size, with a yield corresponding to 20-30 g per individual, depending on the maturity of the female gonad. The results obtained in "giant barnacle" cultures on the Chilean coast indicate that there are spatial differences in growth, both on a latitudinal and local level, as well as bathymetrically and according to the type of culture system. Inter-annual and seasonal temporal differences also exist. Thus, production planning is still subject to a high degree of unpredictability. On the other hand, the heavy weight of the shell, that can fluctuate between 70 to $85 \%$ of total weight, together with high variability in the mortality rate during the growth stage, are also limiting factors for cultures. Nevertheless, in view of its rapid growth and productivity, as well as the simple and economic production technologies used during the fattening phase, culture of the "giant barnacle", and other balanomorphs species, constitutes an interesting alternative for diversification of Aquaculture. 


\subsection{Factors influencing growth}

Experiments conducted under controlled conditions have examined the role of environmental variables in the spatial-temporal variability of "giant barnacle" growth (López et al., 2008a). It has been reported that photoperiod and temperature can synergistically affect the metabolism, influencing molt frequency and growth in some barnacle species (Crisp \& Patel, 1960; El-Komi \& Kajihara, 1991). These variables change seasonally within the geographic distribution range of the "giant barnacle". Temperature and photoperiod affect the instantaneous growth rate, which is greater at $10^{\circ} \mathrm{C}$ than at $16^{\circ} \mathrm{C}$ and at photoperiods of $8 \mathrm{~h}$ light $: 16 \mathrm{~h}$ darkness, than at $16 \mathrm{~h}$ light: $8 \mathrm{~h}$ darkness. Specimens in the natural environment presented higher instantaneous growth rates at depths of between 4 and $6 \mathrm{~m}$ than between 1 and $2 \mathrm{~m}$ depth, under conditions of greater darkness and lower temperature, in accordance with the results obtained in the laboratory. In other species of barnacles, increased growth has also been reported under darkness conditions (Costlow \& Bookhout, 1953; 1956). Futhermore, as occurs in other species of barnacles, growth and molting frequency are not correlated (Costlow \& Bookhout, 1956). In the "giant barnacle" molt frequency was greater at $16^{\circ} \mathrm{C}$ than at $10^{\circ} \mathrm{C}$, with no evidence of variation due to photoperiod. This can be associated with a decreasing metabolism as a result of lower temperatures, or to effects at the neuroendocrine system level. However, the inter-molt periods were longer at $10^{\circ} \mathrm{C}$ than at $16^{\circ} \mathrm{C}$ and during photoperiods 8: 16 than 16:8 (López et al., 2008a). If this information is applied to suspended "giant barnacle" cultures, the fattening phase should be undertaken at depths of over $4 \mathrm{~m}$ and at low temperatures.

\section{Economic aspects}

Of the economically significant species of barnacle, only the "goose barnacles" have an established international market; nevertheless, none of them are cultured on a commercial scale. Species of "acorn barnacles" are consumed on very restricted local markets, although progress has been made in the culture of two species, the "picoroco" in Chile and the"craca in Azores Islands. Thus, in spite of the interesting projections associated with barnacle culture, commercialization remains limited.

\subsection{Product, yield and market}

"Goose barnacles", together with most of the "acorn barnacles", are consumed fresh. Only the "giant barnacle "Austromegabalanus psittacus and the "mine fujit subo" Balanus rostratus, are available in various types of elaborated product. The "giant barnacle" is consumed fresh, frozen and canned, principally on the local Chilean market (Fig. 5). The "mine fujit subo" is consumed fresh, as tempura and as soup flavouring on the Japanese market.

The yield of cultured "giant barnacle" has been determined in a processing plant as $15-20 \%$ of total harvest weight. Loss through processing is approximately 10\% (Bedecarratz et al., 2011). At harvest, specimens reach an average total weight of $150 \mathrm{~g}$, most of which is attributable to the calcareous shell, consisting of six mural plates and two opercular plates. Two, double $100 \mathrm{~m}$ long-lines can produce an average yield of approximately 420 gross ton/year. This doubles the average annual production of artisanal fisheries activities over the last few years in Chile. 


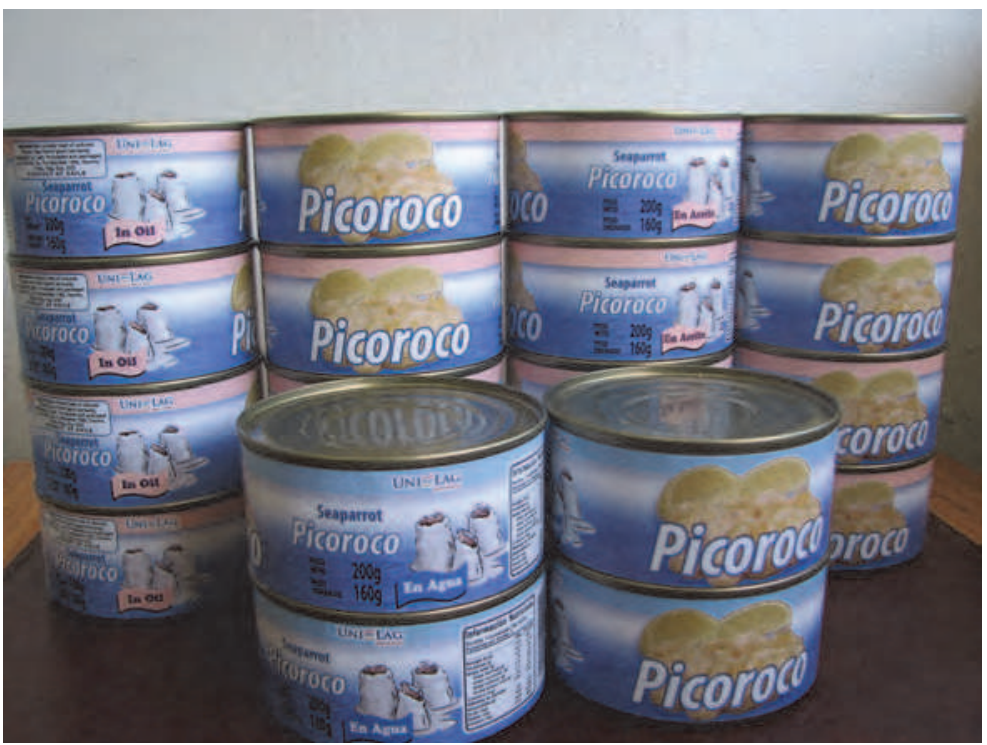

Fig. 5. Canned products of "giant barnacle".

With regard to markets and prices, the "goose barnacles" can reach prices of between $€ 15$ $25 / \mathrm{Kg}$ on the Iberian market. Of the "acorn barnacle" species, the "giant barnacle" is commercialized on the local Chilean market at prices that range between US\$1.5/ Kg and $20 / \mathrm{Kg}$. The "mine fujit subo" reaches between US\$12-15/Kg on the Japanese market and the "craca", between $€ 2.5-5 / \mathrm{Kg}$ on the local market of the Azores Islands, Portugal (López et al., 2010). Market studies of the "giant barnacle" in Japan indicate that some products can reach up to US\$25/Kg. " Giant barnacle" cultures on the Chilean coast have generated an interest in its commercialization in the USA and on the Iberian market.

\subsection{Economic feasibility of "giant barnacle" culture. Financial indicators}

"Giant barnacle" culture is technically and economically feasible based on spat obtained from the wild (Bedecarratz et al., 2011). Nevertheless, the commercial success of these cultures depends on three factors: (a) appropriate selection of culture locations, according to food availability, as well as environmental, oceanographic and climatic conditions. These variables determine spat supply and growth rate, that in turn define the period from spat collection to harvest; (b) effective culture management in order to reduce mortality; (c) ensuring the best prices on external markets by implementing an adequate commercial marketing strategy and exporting the most profitable products.

The financial indicators obtained for frozen and canned products are adequate. The net present value (NPV) is positive for both products; the internal rate of return (IRR) varies between 31-61\% and the discounted payback period (DPBP) varies between 3 and 5 years.

The economic profitability index (EPI) fluctuates between 1.7 and 2.9 and confirms that this aquaculture activity is economically attractive, given that current value of expected cash inflows (at 19.6\% discount rate) exceeds initial investments (Bedecarratz et al., 2011). 
Greatest cash outlay corresponds to production technology (material and labour costs associated with the construction and installation of production technologies). Sensitivity analysis indicates that positive NPC values are maintained, in spite of significant changes in each critical variable, such as: spat density, gross weight, mortality up to harvest, processing and packing costs, FOB sale prices and exchange rate. For elasticity analysis, the most relevant variables are: gross weight at harvest and sale price FOB, while the variable with lowest impact on NPV is processing and packing costs (Bedecarratz et al., 2011).

\section{Conclusions and projections}

\subsection{Advantages of barnacle culture}

"Giant barnacle" culture benefits from advantages over other crustacean delicate meats, such as lobsters or prawns, summarized in López et al., (2010):

a. They are omnivorous filter feeders that consume a wide size-range of phytoplankton and zooplankton. Thus, they have a low trophic level and cultures do not require provision of exogenous food, as a result of which costs and environmental impact are moderate.

b. Although they are gregarious, they do not create culture problems associated with the territorial behaviour of other species. "Giant barnacles" living in groups do not generate density-dependent effects during growth or reproduction, because of their ability to modify their base, thus limiting demand for areas of adhesion to the substrate (López et al., 2007b).

c. Spat can be obtained from the wild in sufficient quantities to permit the development of commercial cultures. This means production costs are low. Spat production in hatcheries ensures reliable supplies, but clearly increases costs (López et al., 2005; 2010; Andrade et al., 2011).

d. They have high growth rates, thus specimens can reach a commercial size in periods that, depending on the requirements of the market, fluctuate between 6 and 18 months (López et al., 2010).

e. They possess early sexual maturity and high fecundity.

f. They have high resistance to environmental variables, particularly hypoxia and to salinity variations, factors that are usually subject to frequent changes, affecting the survival of organisms maintained in suspended cultures (López et al., 2003).

g. Culture technologies are simple and economical, and potential for contamination and mass environmental effects, is low. They occupy limited space.

h. Although real demand has not been completely defined, commercialization prices on international markets are high.

\subsection{Effect of giant barnacle culture on aquaculture diversification in Chile}

Potential for Aquaculture diversification in Chile is high, due to the presence of a large number of economically significant native species of fish, invertebrates and algae. Many of them are exported at high prices; the majority in limited volumes. Fisheries and aquaculture exports in Chile reach around US $\$ 4$ billion and are destined to more than 130 countries. Nevertheless, limitations, generated by the overexploitation of natural populations, exist. Culture options could become a reality if the level of biological knowledge and trial 
experiences aimed at developing adequate production techniques, increase; to date, experimental cultures have been undertaken using around a dozen species (López et al., $2008 \mathrm{~b}$ ). The development of industrial cultures of native species, permits greater predictability in production volumes as well as improved product quality. At present Aquaculture production exceeds 700,000 ton/year. A total of seventeen species are cultured - four algae (11.5\% of production), five species of fish (62.6\%) and eight species of molluscs ( $25.9 \%$ of production). Around $63 \%$ correspond to introduced species, principally salmonids and, to a lesser extent, abalones and the Japanese Oyster. Twenty-five percent includes various species of native molluscs, principally mytilids, the Chilean oyster and the northern scallop (Sernapesca, 2009). However, they are cultured with introduced technologies, developed for similar species in other countries. Only around $14 \%$ correspond to two species of native algae, cultured using national technologies.

Traditional fisheries activities extract 130 species of commercial interest, of which 68 are fish, 29 molluscs, 19 crustaceans, 11 algae and 3 "other" groups. Annual landings reach approximately 2,000,000 ton/year. Seventy-three percent of landings correspond to fish, $19 \%$ algae, $5.2 \%$ molluscs and $0.7 \%$ crustaceans (Sernapesca, 2009). Data reveal interesting and varied alternatives for aquaculture diversification, based on the incorporation of mass cultures of native species. Among these, is the "giant barnacle", about which considerable knowledge has been accumulated regarding biological aspects associated with aquaculture, such as: growth (López et al., 2008a); density-dependent effects (López et al., 2007b); reproduction and life cycle (López \& Toledo, 1979); effects of environmental factors, such as salinity and hypoxia (Vial et al., 1999; López \& López, 2005; López et al., 2003; Simpfendörfer et al., 2005; 2006); and behaviour (López \& López, 2005; López et al., 2008a). Furthermore, the development of production technologies for obtaining spat from the wild and for growth, have permitted culture of the "giant barnacle" on a semi-industrial scale (López, 2008; López et al., 2010).

Although cost and experience of the workforce are important factors affecting the economic feasibility of cultures, present conditions are favourable, due to the increased availability of manual labour with aquaculture experience in southern Chile. This is a consequence of reduced demand for workers in the salmonid production sector, which has been negatively affected by the presence of viral disease (Mardones et al., 2009; Vike et al., 2009). This same causal factor has increased the availability of maritime concessions, processing plants, transport systems and other facilities for new aquacultures activities.

\section{Acknowledgements}

Funds were provided by the Chilean Government (FONDEF Projects D03I1116 and D07I1042), the Autonomous Regional Government of the Azores, Portugal (Projects EPA-I PRODESA 2004.91.001646.0 and PEDAPCA) and the Universidad de Los Lagos, Osorno, Chile, aimed at developing barnacle culture. This financial support is gratefully acknowledged, as is the collaboration of the private companies JAL Fisheries SA (Chile), Cultivos Cholche (Chile), Aquanorte (Chile) Plastimar Ltda (Chile) Octopus Mar SA (Chile), and Sea Expert SA (Azores Islands). In particular, the assistance of José A. López, Justo García, Hugo Ulloa, Pedro González, Luis Pereira, and Henrique Ramos was especially significant. Similarly, the authors appreciate the support of the Universidade dos Açores and the collaboration of the Chilean researchers María Luisa González, Sergio Arriagada, 
Óscar Mora, Verónica Riquelme, Paula Bedecarratz, Mauricio Pineda, José Uribe and Lorenzo Andrade as well as the students Victor Oyarzún, Erwin Aros, Elías Romeri, Haroldo Aburto, Diego Barriga and Alexis Catalán. The contribution of the researchers from the Azores Islands, Mirko Di Girolamo, Rui Guedes and Emanuel Silva, is much appreciated. Our thanks also go to Pedro Ségure of FONDEF-CHILE. Finally, the cooperation of Sandra Mancilla, in the administrative work, Susan Angus, in the translation of the manuscript, and the Editor comments, are much appreciated.

\section{References}

Anderson, D.T. (1994). Barnacles: structure, function, development and evolution. Chapman and Hall, London. U.K.

Andrade, L.I., López, D.A. \& López, B. A. (2011). Dynamic models applied to giant barnacle culture. Aquaculture International (in press).

Akashige, S.T., Kano-noy, H.S. \& Nomura, T. (1981). Effects of gamma-aminobutyric acid and certain neurotransmitters on the settlement of the larvae of Haliotis discus hannai Ino (Gastropoda). Bulletin Tohoku Regional Fishery Research Laboratory 43:37-45.

Anil, A.C., Khandeparker, L., Desai, D.V., Baragi, L.V. \& Gaonkar, C.A. (2010). Larval development, sensory mechanisms and physiological adaptations in acorn barnacles with special reference to Balanus amphitrite. Journal of Experimental Marine Biology and Ecology 392 (1-2): 89-98.

Arenas, J. (1971). Distribución de Elminius kingii Gray (Cirripedia) en el estuario del río Valdivia. Beiträge Zur Neotropical Fauna 6 (3): 199-206.

Bald, J., Borja, A. \& Muxika, I. (2006). A system dynamics model for the management of the gooseneck barnacle (Pollicipes pollicipes) in the marine reserve of Gaztelugatxe (Northern Spain). Ecological Modelling 194 (1-3): 306-315.

Bedecarratz, P.C., López, D.A., López, B.A. \& Mora, O.A. (2011). Economic feasibility of aquaculture of the giant barnacle, Austromegabalanus psittacus in southern Chile. Journal of Shellfish Research 30 (1): 147-157.

Bonar, D., Coon, M., Walch, M., Weiner, R. \& Fitt, W. (1990). Control of oyster settlement and metamorphosis by endogenous and exogenous chemical cues. Bulletin of Marine Sciences 46: 484-498.

Brattström, H. (1990). Intertidal ecology of the northern part of the Chilean Archipelago. Sarsia 75: 105-160.

Brown, S. \& Roughgarden, J. (1985). Growth, morphology, and laboratory culture of Balanus glandula larvae (Cirripedia:Thoracica). Journal of Crustacean Biology 5: 574-590.

Costlow, J.D. \& Bookhout, C. G. (1953). Molting and growth in Balanus improvisus. The Biological Bulletin 105: 420-433.

Costlow, J.D. \& Bookhout, C. G. (1956). Molting and shell growth in Balanus amphitrite niveus. The Biological Bulletin 110 (2): 107-116.

Crisp, D.J. \& Patel, B. S. (1960). The moulting cycle in Balanus balanoides (L.). The Biological Bulletin 118: 31-47.

Cruz, T., Castro, J.J. \& Hawkins, S.J. (2010). Recruitment, growth and population size structure of Pollicipes pollicipes in SW Portugal. Journal of Experimental Marine Biology and Ecology 392 (1-2): 200-209.

Desai, D.V. \& Anil, A.C. (2004). The impact of food type, temperature and starvation on larval development of Balanus amphitrite Darwin (Cirripedia: Thoracica). Journal of Experimental Marine Biology and Ecology 306; 113-137. 
Dionisio, M.A., Rodrigues, A. \& Costa, A. (2007). Reproductive biology of Megabalanus azoricus, (Pilsbry) the Azorean barnacle. Invertebrate Reproduction \& Development 50(3): 155-162.

Dionisio, M.A., Rodrigues, A., Pires, P. \& Costa A. (2009). Bases para a gestão e conservação de Megabalanus azoricus. $1^{\circ}$ Congresso de Desenvolvimento Regional de Cabo Verde $/ 15^{\circ}$ Congresso da APDR. Cidade da Praia, Cabo Verde, Junho de 2009: 319-337.

El-Komi, M.M. \& Kajihara, T. (1991). Breeding and molting of barnacles under rearing conditions. Marine Biology 108: 83-89.

Gaines, S. \& Roughgarden, J. (1985). Larval settlement rate: a leading determinant of structure in an ecological community of the marine intertidal zone. Proceedings of the National Academy of Sciences (USA) 82: 3703-3711.

Gaines, S.D. \& Bertness, M.D. (1992). Dispersal of juveniles and variable recruitment in sessile marine species. Nature 360: 579-580.

Gaines, S.D. \& Bertness, M. (1993). The dynamics of juvenile dispersal - why field ecologists must integrate. Ecology 74: 2430-2435.

Goldberg, H. (1984). Posibilidades de cultivo del percebe, Pollicipes cornucopia Leach, en sistemas flotantes. Informe Técnico. Instituto Español de Oceanografía 19: 1-13.

González, L., Castilla, J. \& Guisado, C. (1987). Effect of larval diet and rearing temperature on metamorphosis and juvenile survival of the sea urchin Loxechinus albus (Molina, 1782) (Echinodermata: Echinoidea). Journal of Shellfish Research 6:109-115.

Hadfield, M . (1986). Settlement and recruitment of marine invertebrates: a perspective and some proposals. Bulletin of Marine Sciences 39: 418-425.

Hills, J. M. \& Thomason, J. C. (2003). The 'ghost of settlement past' determines mortality and fecundity in the barnacle, Semibalanus balanoides. Oikos 101: 529-583.

Jacinto, D,. Cruz, T., Silva T. \& Castro, J.J. (2010). Stalked barnacle (Pollicipes pollicipes) harvesting in the Berlengas Nature Reserve, Portugal: temporal variation and validation of logbook data. ICES Journal of Marine Science. 67: 19-25.

Jenkins, S.R., Aberg, P., Cerving, G., Coleman, R.A., Delany, J., Della, S.P., Hawkins, S.J., Lacroix, E., Myers, A.A., Lindegarth, M., Power, A.M., Robert, M.F. \& Hartnoll, R.G. (2000). Spatial and temporal variation in settlement and recruitment of the intertidal barnacle Semibalanus balanoides (L.) (Crustacea : Cirripedia) over a European scale. Journal of Experimental Marine Biology and Ecology 243: 209-225.

Kirchman, D., Graham, S., Reish, D. \& Mitchell, R. (1982). Bacteria induce settlement and metamorphosis of Janua (Dexiospira) brasiliensis Grube (Polychaeta: Spirorbidae). Journal of Experimental Marine Biology and Ecology 56: 153-163.

Knight-Jones, E.W. (1953). Laboratory experiments on gregariousness during setting in Balanus balanoides and other barnacles. Journal of Experimental Biology 30: 584- 598.

Lagos, N.A., Navarrete, S.A., Veliz, F., Masurero, A. \& Castilla, J.C. (2005). Meso-scale spatial variation in settlement and recruitment of intertidal barnacles along the coast of central Chile. Marine Ecology Progress Series 290: 165-178.

Lagos, N.A., Castilla, J.C. \& Broitman, B. (2008). Spatial environmental correlates of intertidal recruitment: a test using barnacles in northern Chile. Ecological Monographs 78 (2): 245-261.

Li, H.X., Miao, S.Y., Yan, Y., Yu, X.J. \& Zhang, L.P. (2011).Larval Development the Barnacle, Microeuraphia withersi (Cirripedia,Thoracica,Chthamalidae) reared in the laboratory source. Crustaceana 84 (2): 129-152.

Lotaçor (2006). Pescado comercializado nas Lotas de região autónoma dos Açores. Reviewed April 12. Available from:

http://www.lotacor.pt/estatisticas/free/publicacoes_antigas/2006.pdf. 
López, B.A., \& López, D.A.(2005). Moulting frequency and behavioural responses to salinity and diesel oil in Austromegabalanus psittacus (Molina) (Cirripedia: Balanidae). Marine and Freshwater Behaviour and Physiology 38 (4): 249-258.

López, D. (2008) Giant barnacle "picoroco" culture in Chile, in C. K. Pham, R. M. Higgins, M. De Girolamo \& E. Isidro (Eds.), Acta of the International Workshop: Developing a Sustainable Aquaculture Industry in the Azores. Arquipelago. Life and Marine Sciences. Supplement 7: 56-57.

López, D. \& Toledo, G. (1979). Estudio descriptivo comparado de estados larvales tempranos y de cypris de balanomorfos chilenos. Acta Zoologica Lilloana 35: 547- 561.

López, D.A., Castro, J.M., González, M.L. \& Simpfendörfer, R.W. (2003). Physiological responses to hypoxia and anoxia in the giant barnacle, Austromegabalanus psittacus (Molina 1782). Crustaceana 76: 533-545.

López, D.A., López, B.A., González, M.L. \& Arriagada, S.E. (2005). Aquaculture diversification in Chile: potential culture of giant barnacles. Global Aquaculture Advocate 8 (2): 73-74.

López, D.A., López, B.A. \& González, M.L. (2007a). Bibliographic index on aquatic biodiversity of Chile: Crustacea, Cirripedia, Thoracica. Ciencia y Tecnología del Mar 30 (1):161-165.

López, D.A., López, B.A., Burgos, C., Arriagada, S.E. \& González, M.L. (2007b). Consequences of base modification in hummocks of the barnacle Austromegabalanus psittacus. New Zealand Marine and Freshwater Research 41 (3): 291-298.

López, D.A., Espinoza, E.A., López, B.A \& Santibañez, A.F. (2008a). Growth and moulting behaviour in the giant barnacle Austromegabalanus psittacus (Molina, 1782). Revista de Biología Marina y Oceanografía 43 (3): 607-613.

López, D. A, López, B.A. \& González, M.L. (2008b). Shellfish culture in Chile. International Journal of Environment and Pollution 33 (4): 401-431.

López, D.A., López, B.A., Pham, C.K., Isidro, E.J. \& De Girolamo, M. (2010). Barnacle culture: background, potential and challenges. Aquaculture Research 41: e367-e375.

Maki, J.S., Rittschof, D., Costlow, J.D. \& Mitchell, R. (1988). Inhibition of attachment of larval barnacles, Balanus amphitrite, by bacterial surface films. Marine Biology 97: 199-206.

Maki, J.S., Rittschof, D., Schmidt, A.R., Snyder, A. \& Mitchell, R. (1989). Factors controlling attachment of bryozoan larvae: a comparison of bacterial films and unfilmed surfaces. The Biological Bulletin 177: 295-302.

Maki, J.D., Rittschof, O., Samuelsoon, U., Szewzky, A., Yule, B., Kjelleberg, S., Costlow, J.D. \& Mitchell, R. (1990). Effect of marine bacteria and their exopolymers on the attachment of barnacle cypris larvae. Bulletin of Marine Science 46 (2):499-511.

Mardones, F., Pérez, A. \& Carpenter, T. (2009). Epidemiologic investigation of the reemergence of infection salmon anemia virus in Chile. Diseases of Aquatic Organisms 84 (2): 105-114.

Metaxas, A. \& Saunders, M. (2009). Quantifying the bio-components in biophysical models of larval transport in marine benthic invertebrates: Advances and Pitfalls. The Biological Bulletin 216:257-272.

Miller, K.M., Blower, S.M., Hedgecock, D. \& Roughgarden, J. (1989).Comparison of Larvaland adult stages of Chthamalus dalli and Chthamalus fissus (Cirripedia, Thoracica). Journal of Crustacean Biology 9: 2(242-256).

Minchinton, T.E. \& Scheibling, R.E. (1991). The influence of larval supply and settlement on the population structure of barnacles. Ecology 72: 1867-1879.

Mishra, J. K. \& Kitamura, H. (2000). The effect of mono-amino acids on larval settlement of the barnacle, Balanus amphitrite Darwin. Biofouling 14 (4): 299-303. 
Mishra, J.K., Kitamura, H. \& Tomoda, F.I. (2001). Laboratory culture of Balanus trigonus larvae by the method of Balanus amphitrite for establishing a multi-species settlement assay. Sessile Organisms 18 (1):1-6.

Molares, J. \& Freire, J. (2003). Development and perspectives for community-based management of the goose barnacle (Pollicipes pollicipes) fisheries in Galicia (NW Spain). Fisheries Research 65 (1-3): 485-492.

Molares, J., Tilves, F., \& Pascual, C. (1994). Larval development of the pedunculate barnacle Pollicipes cornucopia (Cirripedia: Scalpellomorpha) reared in the laboratory. Marine Biology 120: 261-264.

Morris, R.H., Abbott, D.P. \& Haderlie, E.C. (1980). Intertidal invertebrates of California. Stanford University Press, Palo Alto, California, USA.

Pearce, C.M. \& Scheibiling, R.E. (1990). Induction of settlement and metamorphosis in the sand dollar Echinarachnius parma: evidence for an adult-associated factor. Marine Biology 107: 363-369.

Pham, C.K. \& Silva, E. (2010). New species in european shellfish Aquaculture: barnacle farming in the Azores. Aquaculture Europe 35 (2): 27-29.

Pham, C.K., Higgins, R.M., De Girolamo, M. \& Isidro, M. (2008). Acta of the International Workshop: Developing a Sustainable Aquaculture Industry in the Azores. Arquipelago. Life and Marine Sciences Supplement 7: 1- 81.

Pham, C.K., De Girolamo, M. \& Isidro, E.J. (2011). Recruitment and growth of Megalabanus azoricus (Pilsbry, 1916) on artificial substrates: first steps towards commercial culture in the Azores. Arquipelago. Life and Marine Sciences 28: 47-56.

Pineda, J. (2000). Linking larval settlement to larval transport: assumptions, potentials, and pitfalls. Oceanography of the Eastern Pacific 1: 84-105.

Pineda, J., Reyns, N.B., Starczak, V.R. (2009). Complexity and simplification in understanding recruitment in benthic populations. Population Ecology 51: 17-32.

Pilsbry, H. (1916). The sessile barnacles (cirripedia) contained in the collection of the U.S. National Museum including a monograph of the American species. Bulletin of United States Natural Museum 93: 1-366.

Qiu, J.W. \& Qian, P.Y. (1999) .Effects of salinity and temperature on the life-history of Balanus amphitrite: effects of past experience. Marine Ecology Progress Series 188: 123-132.

Regala, J.T. (1999). Contribuição para o estudo da biologia da craca dos Açores, Megabalanus azoricus (Pilsbry 1916). Relatório de Estágio do Curso de Licenciatura em Biologia Marinha. DOP, Universidade do Algarve, Faro. Portugal

Rittschof, D., Branscomb ,E.S. \& Costlow, J.D. (1984). Settlement and behavior in relation to flow and surface in larval barnacles, Balanus amphitrite Darwin. Journal of Experimental Marine Biology and Ecology 82: 131- 146.

Rodríguez, S.R., Ojeda, F.P. \& Inestrosa, N.C. (1992). Inductores químicos del asentamiento de invertebrados marinos bentónicos: importancia y necesidad de su estudio en Chile. Revista Chilena de Historia Natural 65: 297-310.

Roughgarden, J., Gaines, S. \& Possingham, H. (1988). Recruitment dynamics in complex life cycles. Science 241: 1460-1466.

Santos, R.S., Hawkins, S.J., Monteiro, L.R., Alves, M. \& Isidro, E.J. (1995). ) Marine research resources and conservation in Azores. Aquatic Conservation Marine and Freshwater Ecosystems 5: 311-354.

Sernapesca. (2009). Anuario Estadístico de Pesca. Servicio Nacional de Pesca. Subsecretaria de Pesca, Ministerio de Economía, Fomento y Turismo. Gobierno de Chile. Reviewed June 2011. Available from 
http:/ / www.sernapesca.cl/index.php?option=com_remository\&Itemid=54\&func= select\&id=2.

Simpfendörfer,R.W., Oelkers, K.B., Nash,D. \& López, D.A. (2005). Kinetic properties of the muscular pyruvate kinase from the giant marine barnacle, Austromegabalanus psittacus (Molina , 1782) (Cirripedia, Balanomorpha). Crustaceana 78 (1): 1203-1218.

Simpfendörfer, R.W., Oelkers, K.B \& López, D.A. (2006). Phosphofructokinase from muscle of the marine giant barnacle Austromegabalanus psittacus: Kinetic characterization and effect of in vitro phosphorylation. Comparative Biochemistry and Physiology CToxicology \& Pharmacology 142 (3-4): 382-389.

Southward, A. J. (Ed.). (1987). Crustacean Issues 5. Barnacle Biology. A. A. Balkema. Rotterdam, Netherlands.

Southward, A. J. (1998). New observations on barnacles (Crustacea: Cirripedia) of the Azores region. Arquipelago. Life and Marine Sciences 16a: 11-27.

Thiyagarajan, V., Nair, K.V., Subramoniam, T. \& Venugopalan, V.P. (2002). Larval settlement behaviour of the barnacle Balanus reticulatus in the laboratory. Journal of the Marine Biological Association of the United Kingdom 82: 579-582.

Thiyagarajan, V., Harder, T. \& Qian, P.Y. (2003a). Combined effects of temperature and salinity on larval development and attachment of the subtidal barnacle Balanus trigonus Darwin. Journal of Experimental Marine Biology and Ecology 287: 223-236.

Thiyagarajan, V., Harder, T., Qiu, J.W. \& Qian, P.Y. (2003b). Energy content at metamorphosis and growth rate of the early juvenile barnacle Balanus amphitrite. Marine Biology 143: 543-554.

Thomason, J.C., Hills, J.M., Clare, A. \& Richardson, A.N. (1998). Hydrodynamic consequences of barnacle colonization. Hydrobiologia 375/376: 191-201.

Tremblay, R., Oliver, F., Bourget, E. \& Rittschof, D. (2007). Physiological condition of Balanus amphitrite cyprid larvae determines habitat selection success. Marine Ecology Progress Series 340:1-8.

Vial, M.V., López, D.A., Simpfendörfer, R.W. \& González, M.L. (1999). Responses to environmental hypoxia of balanomorph barnacles. In M. F. Thompson \& R. Nagabhushanam (Eds.), Barnacles. The Biofoulers. Regency Publications, New Delhi, India, 217-244.

Vike, S., Nylund S. \& Nylund, A. (2009). ISA virus in Chile: Evidence of vertical transmission. Archives of Virology 154 (1): 1-8.

Walker, G.( 1995). Larval Settlement: Historical and Future Perspective. In F. R. Schram, F. R. \& J. T. Hoeg. (Eds), Crustacean Issues 10, New frontiers in barnacle evolution, A. A. Balkema, Rotterdam, Netherlands, 69-85.

Yan, Y. \& Chan, B.K. (2001). Larval development of Chthamalus malayensis (Cirripedia: Thoracica) reared in the laboratory. Journal of the Marine Biological Association of the United Kingdom 81 (4):623-632.

Yan, Y. (2003). Larval development of the barnacle Chinochthamalus scutelliformis (Cirripedia: Chthamalidae) reared in the laboratory. Journal of Crustacean Biology 23 (3): 513-525.

Young, P.S. (1998). Maxillopoda. Thecostraca. Catalogue of Crustacea of Brazil. Museo Nacional, Rio de Janeiro, Brazil.

Young, P.S. (2000). Cirripedia thoracica (Crustacea) collected during the "Campagne de La Calypso (1961-1962)" from the Atlantic shelf of South America. Zoosystema 22 (1): 58-100. 


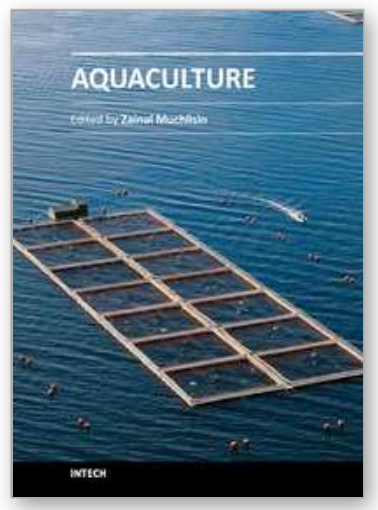

\author{
Aquaculture \\ Edited by Dr. Zainal Muchlisin
}

ISBN 978-953-307-974-5

Hard cover, 390 pages

Publisher InTech

Published online 27, January, 2012

Published in print edition January, 2012

This book provides an understanding on a large variety of aquaculture related topics. The book is organized in four sections. The first section discusses fish nutrition second section is considers the application of genetic in aquaculture; section three takes a look at current techniques for controlling lipid oxidation and melanosis in Aquaculture products. The last section is focused on culture techniques and management, , which is the larger part of the book. The book chapters are written by leading experts in their respective areas. Therefore, I am quite confident that this book will be equally useful for students and professionals in aquaculture and biotechnology.

\title{
How to reference
}

In order to correctly reference this scholarly work, feel free to copy and paste the following:

Daniel A. López, Boris A. López, Christopher K. Pham and Eduardo J. Isidro (2012). Potency of Barnacle in Aquaculture Industry, Aquaculture, Dr. Zainal Muchlisin (Ed.), ISBN: 978-953-307-974-5, InTech, Available from: http://www.intechopen.com/books/aquaculture/potency-of-barnacle-in-aquaculture-industry

\section{INTECH}

open science | open minds

\section{InTech Europe}

University Campus STeP Ri

Slavka Krautzeka 83/A

51000 Rijeka, Croatia

Phone: +385 (51) 770447

Fax: +385 (51) 686166

www.intechopen.com

\section{InTech China}

Unit 405, Office Block, Hotel Equatorial Shanghai

No.65, Yan An Road (West), Shanghai, 200040, China

中国上海市延安西路65号上海国际贵都大饭店办公楼405单元

Phone: $+86-21-62489820$

Fax: +86-21-62489821 
(C) 2012 The Author(s). Licensee IntechOpen. This is an open access article distributed under the terms of the Creative Commons Attribution 3.0 License, which permits unrestricted use, distribution, and reproduction in any medium, provided the original work is properly cited. 